\title{
Book review of Tribal Pastoralists in Transition. The Baharvand of Luristan, Iran by Frank Hole and Sekandar Amanolahi- Baharvand
}

\author{
Richard Tapper(1)
}

\begin{abstract}
Book details
Frank Hole and Sekandar Amanolahi-Baharvand

Tribal Pastoralists in Transition. The Baharvand of Luristan, Iran

Ann Arbor, Michigan: University of Michigan Museum of Anthropology, Anthropological Papers, Number 100; 2021.

xx, 381 pages, ISBN: 978-0-915703-99-9 (print), 978-1-951538-74-3 (ebook)
\end{abstract}

Keywords: Pastoralism, Nomadism, Migration, Archaeology, Iran, Luristan

The mountain ranges, grasslands, and semi-deserts of Iran have long been used exclusively by nomadic or semi-nomadic pastoralists, most of them organized in tribes and tribal confederations. In the late nineteenth century, such pastoralists were estimated at some two million individuals-at least a quarter of Iran's population. In the twentieth century, Reza Shah Pahlavi (19251941) broke the tribal structures and banned nomadic migrations. After 1941, the last Shah's governments officially pursued the same detribalization and settlement policies, but by the late 1960s, pastoral nomad numbers once more neared two million-though now a mere 5\% of the total population and with only vestiges of tribal organization.

In spring 1973, nearly 50 years after Reza Shah's assault on the nomadic tribes, Frank Hole, an experienced archaeologist, and Sekandar Amanolahi, his doctoral student, accompanied a group of Baharvand Lur pastoralists on their spring transhumance from winter pastures not far from the Iraqi frontier up to high summer pastures in the Zagros Mountains, near the small town of

Correspondence: rt3@soas.ac.uk

SOAS University of London, London, UK
Khorramabad. Their book, published nearly another 50 years later, records that migration in detail.

The Lurs (speakers of Luri, a language closely related to Persian and Kurdish) are a diverse group of settled and nomadic people, who include the well-known Bakhtiari and their neighbours the Kohgiluyeh, BoyerAhmad, Mamasani, and others, and all practise agriculture and pastoralism in the middle sections of the long Zagros range of western Iran. Other prominent neighbours are the Kurds to the north-west and the Qashqai and Khamseh tribes to the south-east.

This is largely Hole's book, but it is clear that Amanolahi's input has been vital to the success of the project. Hole has excavated sites in Iran and Syria since the 1950s, focusing on the development of agriculture and pastoralism. His interest in this project was both to identify archaeological sites along the route and to record a pastoral nomad way of life that might provide clues as to life in the camps of the earliest such nomads that he was unearthing elsewhere.

Amanolahi was born in a Lur nomad camp, educated in Iran and then the USA; in 1973, he was conducting doctoral fieldwork under Hole's guidance. Now, one of Iran's senior anthropologists, he has published much on 
the Lurs and nomadism in Iran, in both Persian and English. Here, he has written a fascinating autobiography (chapter 2) and contributed to the general chapters 3 and 4 (on Luristan and its nomads) and 17 (history of the Baharvand), but clearly, the whole project would have been impossible without his personal introduction to their nomad hosts, his daily conversations with Hole, and his role as an interpreter.

Chapters 5-13, the core of the book, are an account by Hole (mostly written up in 1974), of a 2 -week period (dates unspecified, probably April or May) when he and Amanolahi travelled as guests of Amanolahi's distant relative, Morad Khan Baharvand. In his beautifully written narrative of the migration, Hole highlights social and political relations among their hosts and their neighbours, the pastoral nomadic lifestyle, and the problems of nomads in 1973 Iran.

Chapters 6 to 8 are devoted to the first day in Morad Khan's camp and a detailed and intriguing account of the people in the camp, their daily activities and relationships, and their preparations for the first move. The chapters that follow describe the places, events and developing social relationships on the migration, and each covers a range of topics; take the 25 pages of chapter 10 , where my notes on content mention: 'mountains, maps, minerals - and treasure (?); relations and differences; dreams and realities of nomad life (Hole vs Amanolahi); nomadism and settled farming; ancient ruins, earlier civilizations, tombs; a new campsite, making acorn bread, killing a goat for a guest, the distribution of meat in the camp; bonfires, dogs, shrines, Luri cuisine'.

At the end of chapter 13, as the camp arrives in summer quarters, the narrative breaks abruptly as the two authors take off for Khuzistan to pursue a brief archaeological excavation of a site threatened by the vast agribusiness project that is levelling the plains. There, as expected, they unearth sure evidence of 8000-year-old pastoral camps, clearly recognizable to their Lur workers (described in detail in chapter 14), which seems to push the known origins of pastoral nomadism in Iran back several thousand years. They return for a last brief visit to Morad Khan's summer camp (chapter 15). In chapter 16, Hole offers his general observations, colourfully and poetically written, on the nomads' character, their multifaceted adaptations to the environment and to political and economic changes, and more generally the situation of nomads in the twentieth century. In the final chapter 18 , Hole records a brief return visit to their hosts in 2011 and his concluding comments on the huge changes they have experienced.

The narrative is illustrated by numerous photographs that add to the already evocative accounts of people, activities, and places, though there are some unfortunate gaps in the coverage (online, there are some short documentaries shot by Hole on Super-8, but this reviewer did not have access to them).

The book's importance for readers of Pastoralism lies in Hole's colourful and detailed descriptions of events and locations along the migration trek and his ongoing perceptive comments on social relations among the many individuals and families he met. We hear clearly their varied views of the pastoral nomadic life, not least the contrasting perspectives of Hole himself (eager and romantic) and Amanolahi (reluctant and uncomfortable).

There are some possible disappointments. For a start, academic writings on Iran (and the Middle East generally) usefully distinguish nomadism (seasonal movements, change of environment), pastoralism (economic and ritual relations with animals, markets), and tribalism (a range of different modes and levels of social and political organizations). There have always been non-pastoral nomads, settled pastoralists, settled tribes, etc. Yet, this book uses the terms nomads, pastoralists, and tribes(men) interchangeably, just as, in common Persian usage, the standard term ilat va ashayer confuses all three (see Richard Tapper, Change, Cognition and Control: The Reconstruction of Nomadism in Iran, in Chris Hann (ed.) When History Accelerates, London, Athlone, 1994, pp. 188-211).

The authors are aware of some other studies on nomads elsewhere in Iran, but their review in chapter 4 is selective, brief, and not always accurate. They refer to nothing in Persian (e.g. by Amanolahi himself) and little in European languages other than English. They ignore, or represent by a single (often irrelevant) work, major authors in the field. On the Lurs, they give half a paragraph to Jacob Black-Michaud's book on the Hasanvand; they mention, but do not discuss at any length, studies by Carl Feilberg, Inge Mortensen, Reinhold Loeffler, and Erika Friedl-they unfairly dismiss Friedl's and Loeffler's multiple books on the Boyer-Ahmad and Jean-Paul Digard's early study of the Bakhtiari, as 'highly detailed studies of material culture'; they ignore the writings by Susan Wright, Soheila Shahshahani, and others. They discuss at some length three well-known documentaries on the Bakhtiari migration but overlook written accounts of nomadic migrations in Iran, such as Vincent Cronin's classic fictionalised The Last Migration or Lois Beck's Nomad, both on the Qashqai. The bibliography is indeed rather thin, and the book badly needs an index.

Hole's comments are well-constructed and thoughtful, but he does not consider how the Lurs compare to other pastoral nomads in Iran or elsewhere. Rather, in offering his undoubtedly perceptive observations on the problems of Lur nomads in 1973 Iran, he tends to generalise, implying the situation is the same throughout Iran (and elsewhere in the nomadic world); yet, the economic and ecological situation, the history and nature of the tribal organization, and many other factors are specific to 
Luristan. Granted his main interests as an archaeologist are elsewhere, he does not address issues in the anthropological and geographical literature on contemporary nomadism and pastoralism, for example, property rights in animals and in land, the uncertainty/precarity of nomadic pastoralism, and Fredrik Barth's analytical separation of camp-level economics and tribe/state-level politics.

In particular, while liberally using the terms 'tribe' and 'tribal' (as well as 'nomadism' and 'pastoralism'), the authors ignore the debates on what they might refer to. Outmoded in anthropology as useless for analytical purposes, in Iran and the Middle East, 'tribe' is almost unavoidable as a translation of local terms. Here, the authors appear to subscribe to a conventional image of a 'tribe' that was 'purer' in the past but has now been irreversibly transformed by a variety of listed factors. The evidence, here as elsewhere, is that 'tribal' modes of organization among pastoral nomads were always combined with other modes such as class, faction, and community, and they were always flexible and adapted to political circumstances and other forces of change.

Nonetheless, Tribal Pastoralists in Transition offers plenty of material for debates on all these issues-and it is a very good read.

\section{Acknowledgements}

Not applicable.

Author's contributions

The author read and approved the final manuscript.

Funding

None.

Availability of data and materials

Not applicable.

\section{Declarations}

Ethics approval and consent to participate

Not applicable.

Consent for publication

Not applicable.

Competing interests

The author declares that he has no competing interests.

Received: 4 October 2021 Accepted: 4 October 2021

Published online: 08 March 2022

\section{Publisher's Note}

Springer Nature remains neutral with regard to jurisdictional claims in published maps and institutional affiliations.

\section{Submit your manuscript to a SpringerOpen ${ }^{\circ}$ journal and benefit from:}

- Convenient online submission

- Rigorous peer review

- Open access: articles freely available online

High visibility within the field

- Retaining the copyright to your article

Submit your next manuscript at $\boldsymbol{\nabla}$ springeropen.com 